- She ignored the contemporary craze for the Gothic, opting instead for a style modelled on the Romanesque: a simple rectangular building with a semicircular apse, and doors and windows topped with round arches.

She made the building entirely her own by adding decorative carvings that combined rich pre-Christian symbolism with natural forms recently brought to light by fossil-hunters and naturalists. Executed by local craftsmen (and sometimes Losh herself) working mostly in local stone and wood, these anticipated the artistic and architectural ideals set out by John Ruskin a decade after the church was completed. Lotus flowers, ammonites and butterflies embellished windows, doorways and capitals; Losh filled the high windows of the apse with the delicate forms of local fossil ferns cut from translucent sheets of alabaster. More than 30 years after she completed her church, and on a much grander scale, Alfred Waterhouse adopted a Romanesque design decorated with flora and fauna for the Natural History Museum in London. Like Losh, he was inspired by visiting Italy and studying natural history, but Uglow cites no evidence that he knew of Losh's work.

Losh's carvings often feature a pinecone, an ancient symbol of regeneration and enlightenment. Uglow points out that the number of spirals winding up from the base of a pinecone always belongs to the Fibonacci series (running 1, 2, 3, 5, 8 and so on, without end). James Hutton memorably concluded that he could find "no vestige of a beginning, no prospect of an end" in his studies of geological strata. Uglow helps us to see how Losh combined the architectural evidence of past human societies with contemporary invention and discovery, and how she conveyed, through her buildings, a sense of the eternal.

Most of Losh's personal papers and journals, like those of Jane Austen, were lost or destroyed, leaving the biographer to piece together her life from fragments gleaned elsewhere. Sarah Losh remains something of an enigma: a deeply religious woman who built a church that contained no overtly Christian symbols; a devotee of ancient structures and a daughter of the Industrial Revolution; a fashionable beauty and an unmarried scholar and craftswoman.

Sarah Losh chose to express herself in stone, rather than words. In Jenny Uglow, she has found a fine interpreter.

Georgina Ferry is a science writer and author living in Oxford, UK.

e-mail:mgf@georginaferry.com

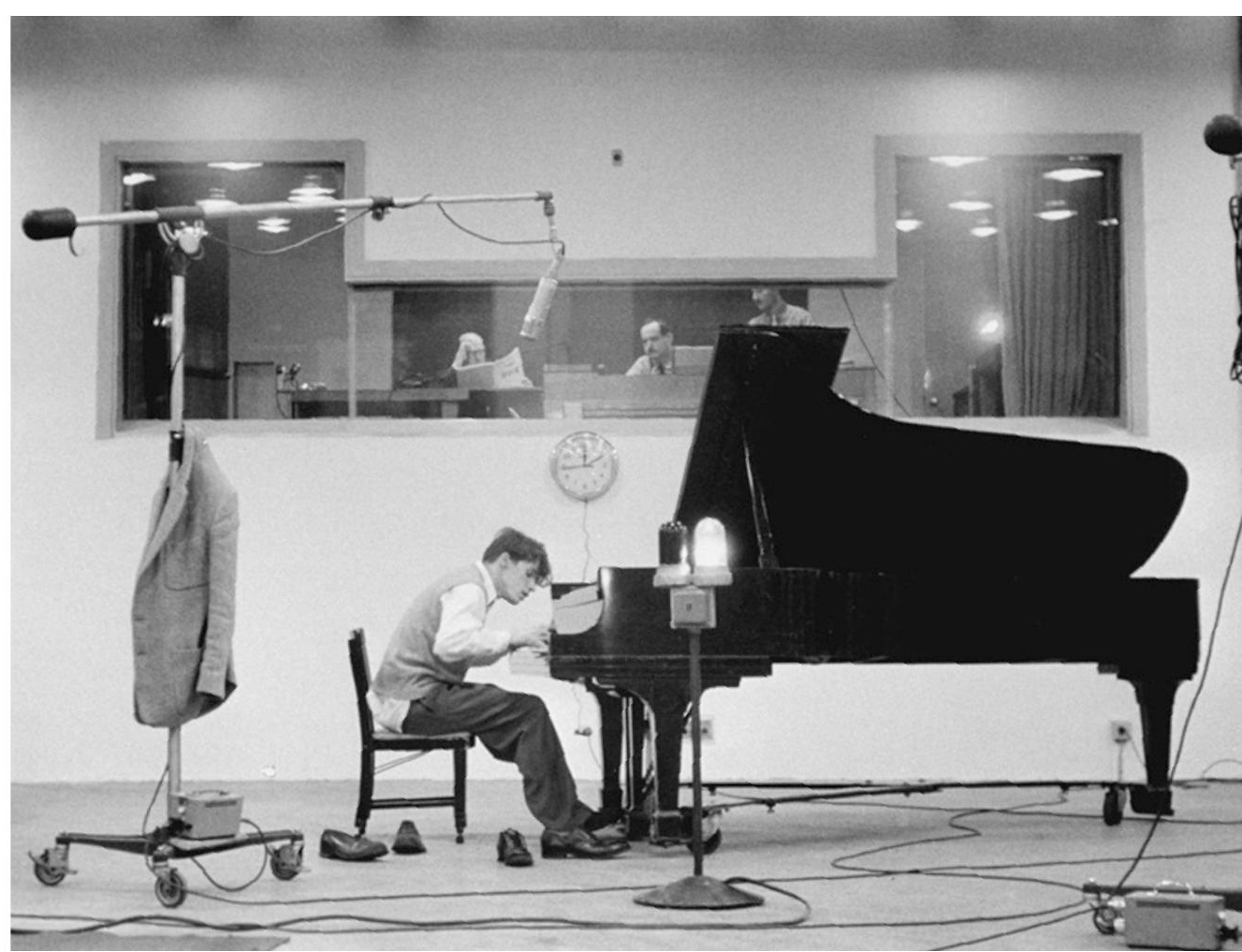

Canadian pianist Glenn Gould recorded Bach's Goldberg Variations twice, in 1955 and 1981.

\title{
TECHNOLOGY
}

\section{Baroque geekery}

\section{Tim Boon assesses a take on the evolving technology behind recordings of J. S. Bach.}

$\mathrm{P}$ aul Elie reveres the music of J. S. Bach and loves some recordings in particular, such as Glenn Gould's 1955 rendition of the Goldberg Variations. In Reinventing Bach Elie sets out to show how technologies - especially developments in recording - have been central to the twentieth century's experience of "the Master's" music.

The book's conceit is that the composer of the Two- and Three-Part Inventions was in some sense an inventor, and so peculiarly attuned to being reinvented - through the recording technologies of the past 100 years or so. And, as Elie shows, the power that recording offered, of enabling repeated listening, also accelerated the rediscovery of Bach by generations of musicians.

Each chapter takes a key recording, dwelling to different degrees on the technology used - disc, tape or digital. The chapters are arranged in roughly chronological order and range from takes by Albert Schweitzer and Leopold Stokowski on the famous Toccata and Fugue in D Minor to Gould's two recordings of the Goldberg Variations
Reinventing Bach PAUL ELIE

Farrar, Straus and

Giroux: 2012

496 pp. £19.99, \$30

events and an accumulating cast of Bach performers and recording artistes.

Throughout, Elie describes the music, not with the technical terminology of the conservatoire, but with metaphor and simile. His characterization of the Toccata and Fugue in D Minor, for instance, reads: "the pipes ring out once, twice, a third time. Then with a long, low swallow the organ fills with sound, which spreads toward the ends of the instrument and settles, pooling there." What he doesn't do, however, is meet the promise in the publisher's blurb to give us "a nuanced and intelligent examination of the technology" that has made the reinvention of Bach possible.

Elie draws on a wide range of published literature, and
DNATURE.COM

For more on recording music, see: go.nature.com/ $\times x 3 \times 22$ 
is insightful about the interplay between technological change and the development of both individual technique and the market for classical music. For example, he describes how Gould's recordings of the Goldberg Variations were polished as the pianist, holed up at a country retreat, repeatedly recorded and listened back to his own performances of the 30 variations on the recently invented tape recorder. Elie also nicely depicts how the historically informed performance scene was stimulated by the arrival of the CD: the clarity of digital recording gave period-music specialists an opportunity to provide newly 'authentic' performances.

But the descriptions of technologies are less sure. Magnetic recording tape does not use silver oxides, as the book has it, but iron oxides. Elie also writes that Schweitzer recorded on cylinders, yet EMI always used discs. His description of a 1905 Victrola gramophone as having a needle converting movements to electrical impulses reads oddly. This is an entirely acoustic device in which even the motor is clockwork; there were no electrical gramophones before the 1920s.

The book would also be stronger for a deeper and more integrated account of musical instruments. The hybrid instrument given to Schweitzer by the Paris Bach Society when he went as a missionary to Africa - enabling him to play in tropical conditions - is described merely as having "the features of a piano and an organ: two manuals, strings and hammers, pedals. The inside of it was lined with zinc to ward off moisture in the tropics". (This amazing-sounding machine can be seen

"The pipes ring out once, twice, a third time. Then, with a long, low swallow the organ fills with sound." in the Maison Albert Schweitzer, the organist's former home, in Alsace, France.) Similarly, Bach's possible involvement in the development of a new instrument called the Lautenwerck, a kind of keyboard-actuated lute, is glossed over in two brief paragraphs - a loss, given the emphasis on Bach as inventor.

In the end, Reinventing Bach reads best as a sincere and compelling account of the author's love of Bach's recorded oeuvre. The passion shines through even though the technology is more marginal than promised. And you may find yourself compelled to rummage through your CD shelves for the works - as I did - revisiting Bach in his multifarious reinventions.

Tim Boon is head of research and public history at the Science Museum in London, UK.

e-mail:tim.boon@sciencemuseum.ac.uk

\section{Books in brief}

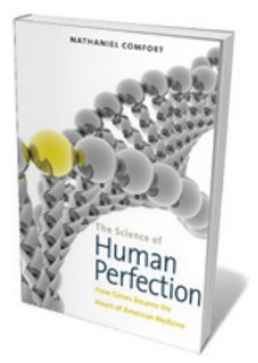

The Science of Human Perfection: How Genes Became the Heart of American Medicine

Nathaniel Comfort YALE UNIVERSITY PRESS 336 pp. £25 (2012)

In this provocative look at genetic medicine in the United States, medical historian Nathaniel Comfort argues that eugenics casts a long shadow over the field. He has researched records spanning a century, following the ever-evolving group of geneticists, eugenicists, psychologists, medics, public-health workers, zoologists and statisticians intent on using heredity to improve human life. Today's hybridized discipline, he says, is noble in intent but rife with social and ethical questions centred on the 'illusion of perfectibility'.

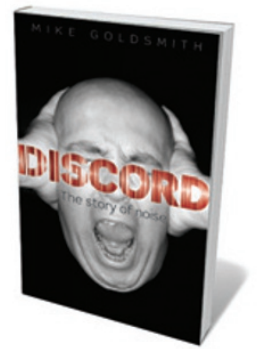

Discord: The Story of Noise

Mike Goldsmith OXFORD UNIVERSITY PRESS 336 pp. £16.99 (2012)

You might pay to hear a jazz saxophonist let rip in a club, but go crazy if they practised next door. Sound in the wrong place is noise, points out science writer and former head of acoustics at the UK National Physical Laboratory Mike Goldsmith in this chronicle of cacophony and our attempts to control it. Starting with the nature of sound and its birth in the infant Universe, he runs through prehistoric noise, the beginnings of acoustical science in the Renaissance, the machine-led din of the Industrial Revolution, the clamorous twentieth century and today's aural pollution from wind farms, underwater sonar and more.

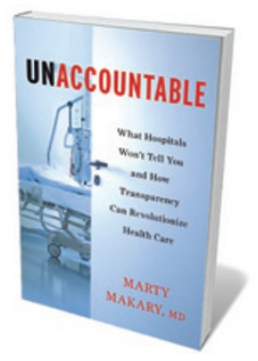

\section{Unaccountable: What Hospitals Won't Tell You and How} Transparency Can Revolutionize Health Care

Martin Makary BLoomSBURY 256 pp. £19.99 (2012)

Surgeon and health-policy specialist Martin Makary reveals US hospitals as battlegrounds between competence and chaos. Serious blunders — such as surgical tools being left in body cavities - are so common that a 2010 study reported that one-quarter of patients are harmed by medical mistakes. Among Makary's mind-bending observations is how two doctors approached the removal of benign colonic polyps. One neatly excised the growth; the other removed half the colon. A powerful plea for openness in US health care.

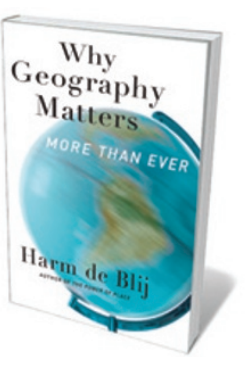

Why Geography Matters, More Than Ever

Harm de Blij OXFORD UNIVERSITY PRESS 320 pp. £10.99 (2012)

Where geopolitics is concerned, Harm de Blij says, it's easy to hit a plus ça change moment. This revised edition of his influential 2007 book includes the rapid shifts and upheavals of the past five years, from the Arab Spring to the European Union's economic wobbles. But de Blij's original premise - that the geographical illiteracy prevalent in the United States seriously impedes coherent policy — is more relevant than ever. With power comes responsibility, and Americans, he says, have an obligation to develop the geographer's perspective on culture, politics, economics and the environment.

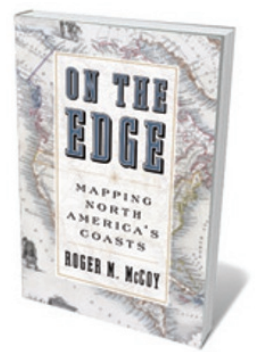

On the Edge: Mapping North America's Coasts

Roger M. McCoy OXFORD UNIVERSITY PRESS 256 pp. £18.99 (2012)

Some 500 years ago, the edges of North America were as mysterious to Europe's explorers as the Moon. Geographer Roger McCoy recounts their voyages and cartographic efforts, starting with John Cabot and Martin Frobisher, and ending with Otto Sverdrup and Vilhjalmur Stefansson in the early twentieth century. The tales of derring-do, brushes with death and brutal behaviour towards native Americans are interspersed with clear explanations of how, over time, this multitude of mariners redrew the New World map. 